\title{
Kinetic approach and balancing of aerobic stabilization of solid wastes in lysimeters
}

\author{
Liliana Krzystek, Radosław Slezak, Anna Zieleniewska-Jastrzebska, Stanisław Ledakowicz \\ Technical University of Lodz, Department of Bioprocess Engineering, Faculty of Process and Environmental Engineering, \\ ul. Wólczańska 213, 90-924 Łódź, e-mail: krzystek@p.lodz.pl
}

\begin{abstract}
Forced aeration of old landfills by an in situ method causes enhanced reduction of leachate indices organic load, a decrease of greenhouse gases emitted to the atmosphere and waste stabilization. The aim of the research was an experimental simulation of aerobic stabilization on landfills carried out under different conditions of leachate recirculation in lysimeters. The results were used in balancing and the kinetic analysis of the organic substance degradation.
\end{abstract}

Keywords: landfills, aerobic solid waste stabilization, lysimeters, leachates, elemental balances.

\section{INTRODUCTION}

Methods for designing and construction of landfills have evolved over the years. Landfills stopped being perceived as dump sites. They are considered as a special type of bioreactors where long-term anaerobic processes proceed ${ }^{1-2}$. Many R\&D centers in the world have been engaged in studies on phenomena that take place during waste dumping as well as in developing methods to stabilize landfills in the shortest possible time. One of such methods is an aerobic landfill model.

The application of forced landfill aeration (an in situ method) causes a parallel reduction of pollutants in leachates, a reduction of methanogenic potential and aerobic stabilization of the landfill ${ }^{3-4}$. To study and optimize waste stabilization, the process is tested by the in situ method both in laboratory conditions ${ }^{5-6}$ and in landfills ${ }^{7-8}$.

The aim of this research was an experimental simulation of aerobic stabilization of landfills carried out in various conditions of leachate recirculation. The results were used in balancing and the kinetic analysis of organic substances degradation.

\section{MATERIALS AND METHODS}

\section{Equipment and Process Parameters}

The experiments were carried out in four identical lysimeters (L1-L4), $1150 \mathrm{~mm}$ high and $150 \mathrm{~mm}$ in inner diameter. The working volume of each lysimeter was 15 $\mathrm{dm}^{3}$. The bottom and top of the lysimeter were free which enabled reception and recirculation of leachates and aeration. Fig. 1 shows a schematic diagram of an experimental set-up. Leachates from the bed of wastes flew down to the lysimeter bottom through a grid supporting the wastes, and next they were collected in a cylinder.

Using a peristaltic pump, the leachates were recirculated at different frequencies. The recirculation was carried out at volumetric flow rates of the leachates equal to $1 \mathrm{ml} / \mathrm{s}$. In lysimeters L1 and L4 the leachates were recirculated seven times a week, in lysimeter L2 three times a week, and in lysimeter L3 once a week. The quantity of leachates recirculated in a week was $6.3 \mathrm{dm}^{3} /$ week in L1 and L4, 2.7 $\mathrm{dm}^{3} /$ week in L2, and $6.3 \mathrm{dm}^{3} /$ week in L3. During aerobic waste stabilization air was introduced to the lysimeter bottom by means of a compressor. The volumetric flow

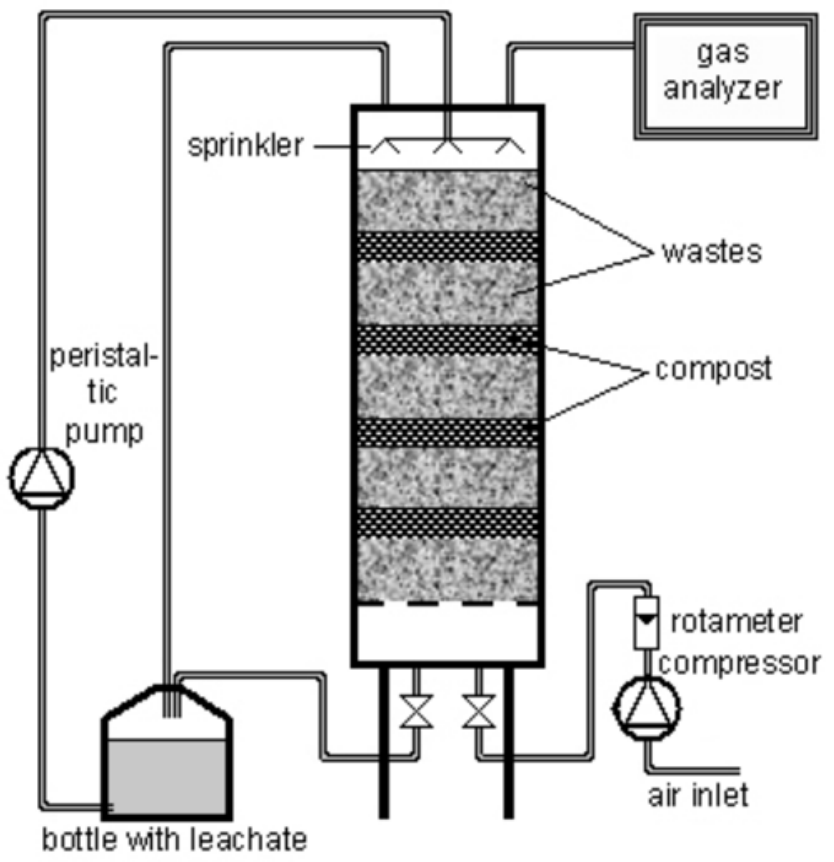

Figure 1. A schematic diagram of the experimental set-up

rate of air supplied to each lysimeter was about $4 \mathrm{dm}^{3} / \mathrm{h}$. The off-gas from the lysimeters flew through a gas analyzer. The processes proceeded in the lysimeters at room temperature (around $20^{\circ} \mathrm{C}$ ).

In the lysimeters filled with wastes for about 5 months the conditions were anaerobic. After reaching a stable methane phase, aeration was started to simulate aerobic stabilization of wastes by the in situ method.

\section{Substrate}

The lysimeters were filled with wastes and compost in alternate layers. The waste composition was similar to the composition of municipal wastes from the city of Łódź9 The mass ratio of particular components of the charge is given in Tab. 1. The wastes were comminuted to the size range from 2 to $4 \mathrm{~cm}$. To 5 kilograms of the charge in the lysimeter $5 \mathrm{dm}^{3}$ water was added.

\section{Analytical Methods}

In the leachates taken from the lysimeters the following indices were analyzed: biochemical oxygen demand $\left(\mathrm{BOD}_{5}\right)\left(\right.$ the dilution method $\left.{ }^{\mathbf{1 0}}\right)$, chemical oxygen demand 
Table 1. Waste composition

\begin{tabular}{|l|c|}
\hline Waste composition & Percentage [\%] \\
\hline Organic wastes & 28 \\
\hline Paper & 19 \\
\hline Plastic & 12 \\
\hline Textile & 4 \\
\hline Compost & 27 \\
\hline Other inorganic wastes & 10 \\
\hline
\end{tabular}

(COD) (dichromate method ${ }^{\mathbf{1 0}}$ ), the content of volatile fatty acids (VFA) (according to Polish Standard PN-75/C04616 using the B-324 Distillation Unit, Büchi), ammonium nitrogen content $\left(\mathrm{N}-\mathrm{NH}_{4}{ }^{+}\right.$) (by the distillation method in a Büchi apparatus), the total nitrogen content (TKN) (by the Kjeldahl method according to Polish Standard PN-75/C04576-17 in a Büchi apparatus) and the total organic carbon (TOC) (702 Li/C Coulomat, Strohlein Instruments, Germany).

In the gas leaving the lysimeter, the concentration of oxygen $\left(\mathrm{O}_{2}\right)$, methane $\left(\mathrm{CH}_{4}\right)$ and carbon dioxide $\left(\mathrm{CO}_{2}\right)$ was measured using a LMS Gas Data.

In the leachates and wastes from lysimeter L4, dry matter and dry organic matter were determined according to Polish Standard PN-75/C-04616.01. The wastes and leachates were subjected to elemental analysis using a NA 2500-M apparatus (CE Instruments).

\section{RESULTS AND DISCUSSION}

\section{The Effect of Leachate Recirculation}

Basing on the experimental investigation of aerobic waste stabilization the highest reduction degree of leachate indices was observed for the content of volatile fatty acids (VFA) and biochemical oxygen demand $\left(\mathrm{BOD}_{5}\right)$, while the lowest one for chemical oxygen demand (COD), the total nitrogen content (TKN) and the total organic carbon content (TOC). With an increase of the leachate recirculation frequency, there was an increase of the reduction degree of VFA, TOC, COD and the total nitrogen content (TKN). Changes in the reduction degree for particular indices are presented in Tab. 2.

Table 2. The reduction degree of particular leachate indices

\begin{tabular}{|l|c|c|c|}
\hline Index [\%] & $\begin{array}{c}\mathrm{L} 1 \\
6.3 \mathrm{dm}^{3} / \text { week }\end{array}$ & $\begin{array}{c}\mathrm{L} 2 \\
2.7 \mathrm{dm}^{3} / \text { week }\end{array}$ & $\begin{array}{c}\text { L3 } \\
0.9 \mathrm{dm}^{3} / \text { week }\end{array}$ \\
\hline $\mathrm{BOD}_{5}$ & 98.2 & 63.9 & 80.7 \\
\hline $\mathrm{COD}$ & 35.8 & 21.6 & 10.5 \\
\hline $\mathrm{VFA}$ & 94.5 & 89.3 & 78.1 \\
\hline $\mathrm{TOC}$ & 34.0 & 16.2 & 14.7 \\
\hline $\mathrm{N}-\mathrm{NH}_{4}{ }^{+}$ & 45.8 & 68.3 & 55.7 \\
\hline $\mathrm{TKN}$ & 43.2 & 18 & -7.5 \\
\hline
\end{tabular}

These results show that the highest reduction of organic load and nitrogen was obtained in lysimeter L1, with the recirculation of $6.3 \mathrm{dm}^{3} /$ week. The least advantageous conditions for leachate index reduction were in lysimeter $\mathrm{L} 3$ at leachate recirculation equal to $0.9 \mathrm{dm}^{3} /$ week.

\section{Elemental Balances}

To describe the stoichiometry of organic matter degradation in lysimeters a black box model was used. Taking into account the molecular composition of reagents participating in transformations, the stoichiometric form of the equation was formulated:

$$
\begin{gathered}
\frac{\mathrm{CH}_{\mathrm{a} 1} \mathrm{O}_{\mathrm{b} 1} \mathrm{~N}_{\mathrm{c} 1}}{\mathrm{~A}}+\mathrm{Y}_{\mathrm{A}, \mathrm{B}} \frac{\mathrm{CH}_{\mathrm{a} 2} \mathrm{O}_{\mathrm{b} 2} \mathrm{~N}_{\mathrm{c} 2}}{\mathrm{~B}}+\mathrm{Y}_{\mathrm{A}, \mathrm{C}} \frac{\mathrm{O}_{2}}{\mathrm{C}} \rightarrow \\
\mathrm{Y}_{\mathrm{A}, \mathrm{D}} \frac{\mathrm{CH}_{\mathrm{a} 3} \mathrm{O}_{\mathrm{b} 3} \mathrm{~N}_{\mathrm{c} 3}}{\mathrm{D}}+\mathrm{Y}_{\mathrm{A}, \mathrm{E}} \frac{\mathrm{CH}_{\mathrm{a} 4} \mathrm{O}_{\mathrm{b} 4} \mathrm{~N}_{\mathrm{c} 4}}{\mathrm{E}}+\mathrm{Y}_{\mathrm{A}, \mathrm{F}} \frac{\mathrm{N}_{2}}{\mathrm{~F}}+\mathrm{Y}_{\mathrm{A}, \mathrm{G}} \frac{\mathrm{CO}_{2}}{\mathrm{G}}+\mathrm{Y}_{\mathrm{A}, \mathrm{H}} \frac{\mathrm{H}_{2} \mathrm{O}}{\mathrm{H}}
\end{gathered}
$$

where: reagent $\mathrm{A}\left(\mathrm{CH}_{\mathrm{a} 1} \mathrm{O}_{\mathrm{b} 1} \mathrm{~N}_{\mathrm{c} 1}\right)$ represents the molecular composition of organic matter contained in the wastes before aeration, reagent $\mathrm{B}\left(\mathrm{CH}_{\mathrm{a} 2} \mathrm{O}_{\mathrm{b} 2} \mathrm{~N}_{\mathrm{c} 2}\right)$ - the molecular composition of organic matter in the leachates before aeration, reagent $\mathrm{C}\left(\mathrm{O}_{2}\right)$ - assimilated oxygen in the lysimeter, reagent $\mathrm{D}\left(\mathrm{CH}_{\mathrm{a} 3} \mathrm{O}_{\mathrm{b} 3} \mathrm{~N}_{\mathrm{c} 3}\right)$ - the molecular composition of organic matter in the wastes after aeration, reagent $\mathrm{E}\left(\mathrm{CH}_{\mathrm{a} 4} \mathrm{O}_{\mathrm{b} 4} \mathrm{~N}_{\mathrm{c} 4}\right)$ - the molecular composition of organic matter in the leachates after aeration, reagent $\mathrm{F}$ $\left(\mathrm{N}_{2}\right)$ - molecular nitrogen produced in the lysimeter, reagent $\mathrm{G}\left(\mathrm{CO}_{2}\right)$ - carbon dioxide formed in the lysimeter, reagent $\mathrm{H}\left(\mathrm{H}_{2} \mathrm{O}\right)$ water generated during aerobic stabilization of wastes. In order to determine yield coefficients the A reagent was chosen as a reference. Tab. 3 gives the molecular composition of reagents $\mathrm{A}, \mathrm{B}, \mathrm{D}$ and E. The molecular formulae of organic matter in the wastes and leachates were determined on the basis of the content of elements $\mathrm{C}, \mathrm{H}, \mathrm{N}$ and $\mathrm{O}$.

Table 3. The molecular composition of wastes and leachates

\begin{tabular}{|l|c|}
\hline Reagents & Molecular formula of the compound \\
\hline A & $\mathrm{CH}_{1.07} \mathrm{O}_{0.83} \mathrm{~N}_{0.047}$ \\
\hline $\mathrm{B}$ & $\mathrm{CH}_{1.58} \mathrm{O}_{0.02} \mathrm{~N}_{0.03}$ \\
\hline D & $\mathrm{CH}_{1.06} \mathrm{O}_{1.25} \mathrm{~N}_{0.043}$ \\
\hline E & $\mathrm{CH}_{1.24} \mathrm{O}_{0.65} \mathrm{~N}_{0.054}$ \\
\hline
\end{tabular}

Symbol I denotes the reagents (A, B and C) which entered the black box, while symbol $\mathrm{O}$ - the reagents $(\mathrm{D}$, E, F, G and H) which left the black box after aerobic waste stabilization. The elemental balance for particular elements was as follows:

for carbon $(\mathrm{C})$

$-1-\mathrm{Y}_{\mathrm{A}, \mathrm{B}}+\mathrm{Y}_{\mathrm{A}, \mathrm{D}}+\mathrm{Y}_{\mathrm{A}, \mathrm{E}}+\mathrm{Y}_{\mathrm{A}, \mathrm{G}}=0$

for hydrogen $(\mathrm{H})$

$-\mathrm{a} 1-\mathrm{Y}_{\mathrm{A}, \mathrm{B}} \cdot \mathrm{a} 2+\mathrm{Y}_{\mathrm{A}, \mathrm{D}} \cdot \mathrm{a} 3+\mathrm{Y}_{\mathrm{A}, \mathrm{E}} \cdot \mathrm{a} 4+\mathrm{Y}_{\mathrm{A}, \mathrm{H}} \cdot 2=0$

for oxygen $(\mathrm{O})$

$-\mathrm{b} 1-\mathrm{Y}_{\mathrm{A}, \mathrm{B}} \cdot \mathrm{b} 2-\mathrm{Y}_{\mathrm{A}, \mathrm{C}} \cdot 2+\mathrm{Y}_{\mathrm{A}, \mathrm{D}} \cdot \mathrm{b} 3+\mathrm{Y}_{\mathrm{A}, \mathrm{E}} \cdot \mathrm{b} 4+\mathrm{Y}_{\mathrm{A}, \mathrm{G}} \cdot 2+\mathrm{Y}_{\mathrm{A}, \mathrm{H}}=0$

for nitrogen $(\mathrm{N})$

$-\mathrm{cl}-\mathrm{Y}_{\mathrm{A}, \mathrm{B}} \cdot \mathrm{c} 2+\mathrm{Y}_{\mathrm{A}, \mathrm{D}} \cdot \mathrm{c} 3+\mathrm{Y}_{\mathrm{A}, \mathrm{E}} \cdot \mathrm{c} 4+\mathrm{Y}_{\mathrm{A}, \mathrm{F}} \cdot 2=0$

Tab. 4 presents the experimentally determined yield coefficients.

From equation (3) which describes hydrogen balance, water yield coefficient $\mathrm{Y}_{\mathrm{A}, \mathrm{H}}$ equal to $0.016 \mathrm{~mol}_{\mathrm{H}} / \mathrm{C}-\mathrm{mol}_{\mathrm{A}}$ was determined. Yield coefficient $\mathrm{Y}_{\mathrm{A}, \mathrm{F}}$ which represents molecular nitrogen production, was calculated from the equation of nitrogen balance (5). It was $0.0025 \mathrm{~mol}_{\mathrm{F}} / \mathrm{C}$ $\mathrm{mol}_{\mathrm{A}}$. The final form of the equation which describes the processes occurring in lysimeter L 4 during aerobic stabilization, was:

$$
\begin{gathered}
\mathrm{CH}_{1.07} \mathrm{O}_{0.83} \mathrm{~N}_{0.047}+0.00237 \mathrm{CH}_{1.58} \mathrm{O}_{0.02} \mathrm{~N}_{0.03}+0.1 \mathrm{O}_{2} \rightarrow \\
0.985 \mathrm{CH}_{1.06} \mathrm{O}_{1.25} \mathrm{~N}_{0.043}+0.00028 \mathrm{CH}_{1.24} \mathrm{O}_{0.65} \mathrm{~N}_{0.054}+ \\
+0.0025 \mathrm{~N}_{2}+0.0496 \mathrm{CO}_{2}+0.016 \mathrm{H}_{2} \mathrm{O}
\end{gathered}
$$

The coefficient of oxygen demand per $1 \mathrm{C}$-mol not aerated wastes was $0.1 \mathrm{~mol}_{\mathrm{C}} / \mathrm{C}$ - $\mathrm{mol}_{\mathrm{A}}$. From one $\mathrm{C}$-mol of the non-aerated wastes $0.05 \mathrm{~mol}$ of carbon dioxide was formed. From carbon balance described by equation (2) the error between input (I) and output $(\mathrm{O})$ was $3.1 \%$ (I $=1.002, \mathrm{O}=1.035)$. For oxygen equation (4) the error was $23.1 \%(\mathrm{I}=1.034, \mathrm{O}=1.346)$. 
Table 4. The experimental yield coefficients

\begin{tabular}{|c|c|c|c|c|}
\hline \multicolumn{5}{|c|}{ Yield coefficient } \\
\hline $\mathrm{Y}_{\mathrm{A}, \mathrm{B}}$ & $\mathrm{Y}_{\mathrm{A}, \mathrm{C}}$ & $\mathrm{Y}_{\mathrm{A}, \mathrm{D}}$ & $\mathrm{Y}_{\mathrm{A}, \mathrm{E}}$ & $\mathrm{Y}_{\mathrm{A}, \mathrm{G}}$ \\
\hline $\mathrm{C}-\mathrm{mol}_{\mathrm{B}} / \mathrm{C}-\mathrm{mol}_{\mathrm{A}}$ & $\mathrm{mol}_{\mathrm{C}} / \mathrm{C}-\mathrm{mol}_{\mathrm{A}}$ & $\mathrm{C}-\mathrm{mol}_{\mathrm{D}} / \mathrm{C}-\mathrm{mol}_{\mathrm{A}}$ & $\mathrm{C}-\mathrm{mol}_{\mathrm{E}} / \mathrm{C}-\mathrm{mol}_{\mathrm{A}}$ & $\mathrm{mol}_{\mathrm{G}} / \mathrm{C}-\mathrm{mol}_{\mathrm{A}}$ \\
\hline 0.00237 & 0.1 & 0.985 & 0.00028 & 0.0496 \\
\hline
\end{tabular}

\section{The Kinetic Model}

During aerobic stabilization of wastes, as a result of degradation of organic substances, cell biomass and gas products of energy processes are formed. A kinetic analysis was made for the substrates, taking into account the changes in the content of volatile fatty acids (VFA) in the leachates and in the content of $\mathrm{CO}_{2}$ in the gas leaving the lysimeter.

The description of the kinetics was based on the assumption that VFA degradation in the leachates was the first-order reaction and the carbon dioxide yield from VFA was constant:

$\frac{\mathrm{dS}}{\mathrm{dt}}=-\mathrm{k} \cdot \mathrm{S}$

After separation of variables and integration in the range from $\mathrm{t}=0$ and $\mathrm{S}=\mathrm{S}_{\mathrm{o}}$ to $\mathrm{t}=\mathrm{t}$ and $\mathrm{S}=\mathrm{S}$, we have:

$\mathrm{S}=\mathrm{S}_{\mathrm{o}} \mathrm{e}^{-\mathrm{kt}}$

where: $S_{o}$ - initial concentration of VFA, $k$ - rate constant selected so as to obtain the best fitting of the model to experimental data (constant $\mathrm{k}$ was calculated using the OriginPro7 program).

The yield of carbon dioxide production from volatile fatty acids is:

$\mathrm{Y}_{\mathrm{S}, \mathrm{P}}=\frac{\mathrm{P}-\mathrm{P}_{\mathrm{o}}}{\mathrm{S}_{\mathrm{o}}-\mathrm{S}}$

The initial concentration of carbon dioxide $\left(\mathrm{P}_{\mathrm{o}}\right)$ was equal to 0 . Upon transformation of equation (9) the following relation is obtained:

$\mathrm{S}=\mathrm{S}_{\mathrm{o}}-\frac{\mathrm{P}}{\mathrm{Y}_{\mathrm{S}, \mathrm{P}}}$

After substituting equation (8) to equation (10), we have:

$\mathrm{P}=\mathrm{Y}_{\mathrm{S}, \mathrm{P}} \mathrm{S}_{\mathrm{o}}\left(1-\mathrm{e}^{-\mathrm{kt}}\right)$

Equation (11) was used in modeling the changes of carbon dioxide during waste aeration. Constant $\mathrm{Y}_{\mathrm{S}, \mathrm{P}}$ was selected so as to obtain the best fitting of the model to the experimental data. Calculations were made using OriginPro7.

Fitting of the kinetic model to the experimental data describing the changes in the concentration of volatile fatty acids and released carbon dioxide is shown in Fig. 2, 3 and 4 . The points represent the experimental data, while the solid line illustrates the kinetic model.

Tab. 5 demonstrates the correlation coefficient $\left(\mathrm{R}^{\wedge} 2\right)$ calculated as a yield coefficient of carbon dioxide related to volatile fatty acids $\left(\mathrm{Y}_{\mathrm{S}, \mathrm{P}}\right)$ and the decomposition rate

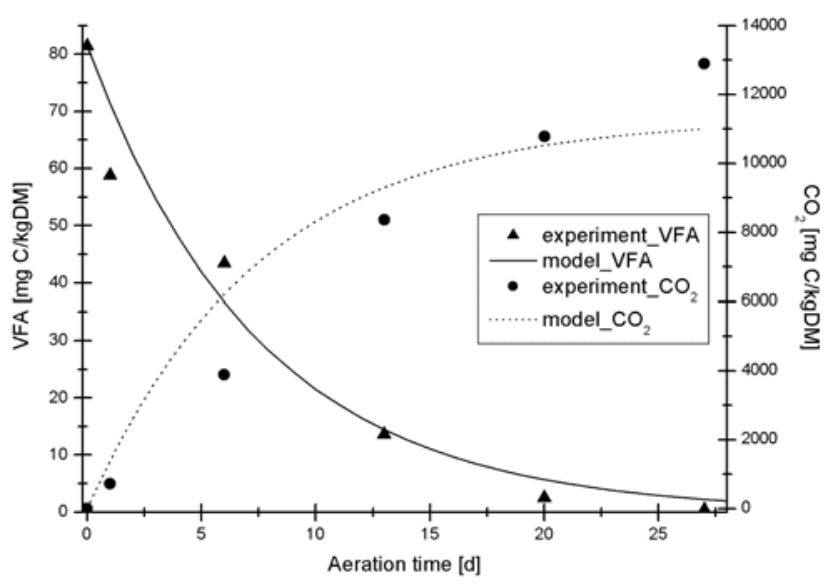

Figure 2. Changes of VFA and $\mathrm{CO}_{2}$ for lysimeter L1

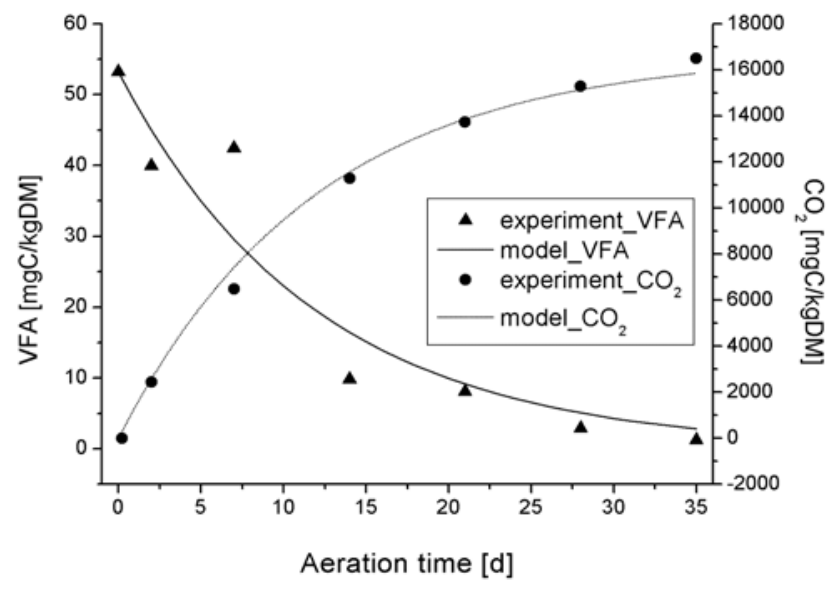

Figure 3. Changes of VFA and $\mathrm{CO}_{2}$ for lysimeter $\mathrm{L} 2$

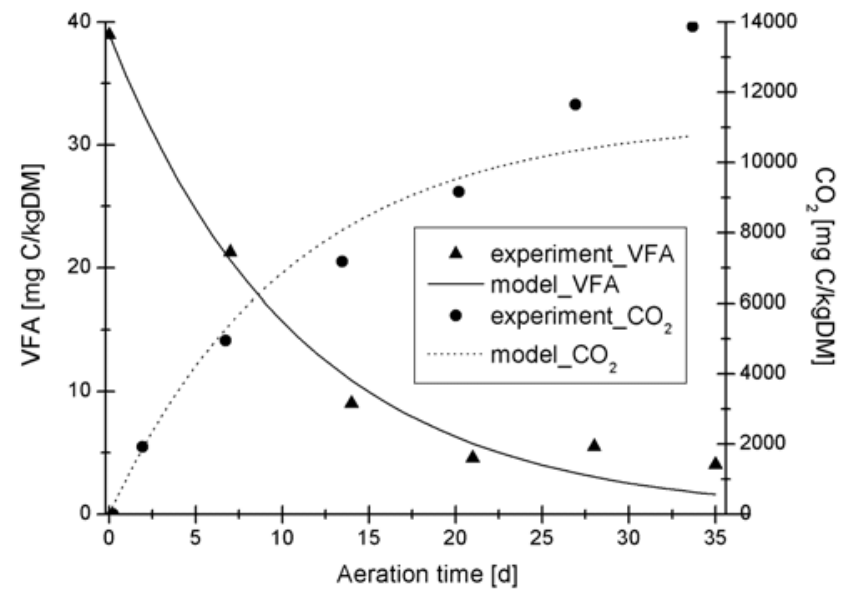

Figure 4. Changes of VFA and $\mathrm{CO}_{2}$ for lysimeter $\mathrm{L} 3$

Table 5. The correlation coefficient, the yield coefficient and the decomposition rate constant of VFA

\begin{tabular}{|c|c|c|c|c|c|c|}
\hline & \multicolumn{2}{|c|}{$\begin{array}{c}\mathrm{L} 1 \\
6.3 \mathrm{dm}^{3} / \text { week }\end{array}$} & \multicolumn{2}{|c|}{$\begin{array}{c}\mathrm{L} 2 \\
2.7 \mathrm{dm}^{3} / \text { week }\end{array}$} & \multicolumn{2}{|c|}{$\begin{array}{c}\text { L3 } \\
0.9 \mathrm{dm}^{3} / \text { week }\end{array}$} \\
\hline & VFA & $\mathrm{CO}_{2}$ & VFA & $\mathrm{CO}_{2}$ & VFA & $\mathrm{CO}_{2}$ \\
\hline$k\left[d^{-1}\right]$ & 0.133 & & 0.0838 & & 0.091 & \\
\hline $\mathrm{Y}_{\mathrm{S}, \mathrm{P}}\left[\mathrm{mg} \mathrm{C}_{\mathrm{P}} / \mathrm{mg} \mathrm{C}_{\mathrm{S}}\right]$ & & 139 & & 314 & & 288 \\
\hline$R^{\wedge} 2$ & 0.96 & 0.93 & 0.91 & 0.99 & 0.98 & 0.97 \\
\hline
\end{tabular}


constant of volatile fatty acids $(\mathrm{k})$ at different recirculation rates of the leachates.

In all the cases the correlation coefficient was bigger than 0.9 which proved good fitting of the kinetic model to the experimental data. The yield coefficient of carbon dioxide from the volatile fatty acid $\left(\mathrm{Y}_{\mathrm{S}, \mathrm{P}}\right)$ ranged from 139 in lysimeter $\mathrm{L} 1$, to $314 \mathrm{mg} \mathrm{C} / \mathrm{mg} \mathrm{C}$ in lysimeter $\mathrm{L} 2$. The rate constant of VFA consumption was the highest in lysimeter L1 $0.133 \mathrm{~d}^{-1}$, and the lowest $0.0838 \mathrm{~d}^{-1}$ in lysimeter L2.

\section{CONCLUSIONS}

- In view of the reduction of leachate indices the best frequency of recirculation was reported in the case when the leachates were recirculated seven times a week. The least favorable conditions for the reduction of leachate indices were observed at the smallest recirculation of leachates in lysimeter L3. At all recirculation frequencies the higest reduction degree was reported for VFA and $\mathrm{BOD}_{5}$, while the smallest one for COD, TKN and TOC. It was observed that with an increase of the recirculation frequency the reduction degree increased for VFA, TOC, COD and TKN.

- From the formulated elemental balance describing the aerobic waste stabilization it follows that around $5 \%$ organic carbon was released from the wastes in the form of carbon dioxide $\left(\mathrm{CO}_{2}\right)$. About $10 \%$ organic nitrogen was removed from the wastes as molecular nitrogen $\left(\mathrm{N}_{2}\right)$. The oxygen demand coefficient per $1 \mathrm{C}$-mol of not aerated wastes was $0.1 \mathrm{~mol}_{\mathrm{C}} \mathrm{C}-\mathrm{mol}_{\mathrm{A}}$. From $1 \mathrm{C}$-mol of not aerated wastes $0.05 \mathrm{C}$-mol carbon dioxide was produced. It was also observed that in the balance leachates could be omitted because the concentration of carbon and organic nitrogen in the leachates was on a very low level in reference to the concentration of nitrogen and organic carbon in the wastes.

- The proposed kinetic model describing changes in carbon dioxide emission depending on the changes in the content of volatile fatty acids in the leachates, at different recirculation rates, well describes the experimental data. The kinetic model was based on the assumption that the degradation of volatile fatty acids was the first-order reaction, and the coefficient of carbon dioxide yield from volatile fatty acids was constant.

\section{NOMENCLATURE}

$\mathrm{BOD}_{5} \quad$ - biochemical oxygen demand, $\mathrm{mg} \mathrm{O}_{2} / \mathrm{dm}^{3}$

COD - chemical oxygen demand, $\mathrm{mg} \mathrm{O}_{2} / \mathrm{dm}^{3}$

DM - dry matter, $\mathrm{kg}$

I - - reagents entering the black box

$\mathrm{k}-$ - decomposition rate constant of volatile fatty acids, $\mathrm{d}^{-1}$

VFA - volatile fatty acids, $\mathrm{mg} \mathrm{CH}_{3} \mathrm{COOH} / \mathrm{dm}^{3}$

TKN - total nitrogen, $\mathrm{mg} \mathrm{N} / \mathrm{dm}^{3}$

$\mathrm{N}-\mathrm{NH}_{4}{ }^{+} \quad-$ ammonium nitrogen, $\mathrm{mg} \mathrm{N} / \mathrm{dm}^{3}$

$\mathrm{O}$

$\mathrm{P}$

- reagents leaving the black box

- carbon dioxide concentration in gas leaving the lysimeter, $\mathrm{mg} \mathrm{C} / \mathrm{kg} \mathrm{SM}$

S

- concentration of volatile fatty acids in leachates, mg C/kg SM

$\mathrm{t} \quad-$ aeration time, $\mathrm{d}$
TOC - total organic carbon, $\mathrm{mg} \mathrm{C} / \mathrm{dm}^{3}$

$\mathrm{Y} \quad-$ yield coefficient, $\mathrm{C}-\mathrm{mol} / \mathrm{C}-\mathrm{mol}_{\mathrm{A}}$ (for reagents $\mathrm{C}, \mathrm{F}$ and $\mathrm{H}$ unit given in $\mathrm{mol} / \mathrm{C}-\mathrm{mol}_{\mathrm{A}}$, in chapter the kinetic model unit given in $\mathrm{mg}_{\mathrm{P}} / \mathrm{mg} \mathrm{C}_{\mathrm{S}}$ )

\section{SUBSCRIPTS}

a1, b1, c1 - constants in the molecular formula of reagent $A$

a2, b2, c2 - constants in the molecular formula of reagent $B$

a3, b3, c3 - constants in the molecular formula of reagent $\mathrm{D}$

a4, b4, c4 - constants in the molecular formula of reagent $\mathrm{E}$

A $\quad-$ reagent $\mathrm{A}$ (organic matter in the wastes before aeration)

B - reagent B (organic matter in the leachates before aeration)

C - reagent $\mathrm{C}$ (oxygen)

D - reagent D (organic matter in the wastes after aeration)

$\mathrm{E}-$ - reagent $\mathrm{E}$ (organic matter in the leachates after aeration)

$\mathrm{F} \quad$ - reagent $\mathrm{F}$ (molecular nitrogen)

$\mathrm{G} \quad$ - reagent $\mathrm{G}$ (carbon dioxide)

$\mathrm{H} \quad-$ reagent $\mathrm{H}$ (water)

$0 \quad-$ initial concentration

$\mathrm{P} \quad-$ carbon dioxide

S $\quad-$ volatile fatty acids

\section{LITERATURE CITED}

1. Pohland, F.G. (1994). Landfill bioreactors: historical perspective, fundamental principals, and new horizons in design and operation. EPA/600/R-95/146:9-24.

2. Purcell, B. (2000). Aerox landfilling: the operational implications. Wastes Management (2000), 27 - 28.

3. Stessel, R. \& Murphy, R. (1992). A lysimeter study of the aerobic landfill concept. Waste Management \& Research $10,485-503$.

4. Warith, M. (2002). Bioreactor landfills: experimental and field results. Waste Management 22, 7 - 17 .

5. Prantl, R., Tesar, M., Huber-Humer, M. \& Lechner, P.(2006). Changes in carbon and nitrogen pool during insitu aeration of old landfills under varying conditions. Waste Management 26, 373 - 380.

6. Ritzkowski, M., Heyer, K.-U., \& Stegmann, R. (2006). Fundamental processes and implications during in situ aeration of old landfills. Waste Management 26, 356 - 372.

7. Cossu, R., Raga, R. \& Rossetti, D. (2003). Full scale application of in situ aerobic stabilization of old landfills. Proceedings Sardinia 2003, Ninth International Waste Management and Landfill Symposium, Cagliari, Italy.

8. Ritzkowski, M., Heyer, K.-U., \& Stegmann, R. (2003). In situ aeration of old landfills: carbon balances, temperatures and settlements. Proceedings Sardinia 2003, Ninth International Waste Management and Landfill Symposium, Cagliari, Italy.

9. Ledakowicz, S. \& Kaczorek, K.(2004). The effect of advanced oxidation processes on leachate biodegradation recycling lysimeters. Waste Management \& Research 22, $149-157$.

10. Standard Methods for the Examination of Water and Wastewater. (1989). American Public Health Association, Washington, D.C., 17th edition. 